\title{
Student Centre Approach in Teaching English for Specific Purposes Moodle-Based
}

\author{
Rizky Eka Prasetya \\ Akademi Sekretari Budi Luhur \\ rizky.ekaprasetya@budiluhur.ac.id
}

\begin{abstract}
The Indonesia higher education majority utilized the Language Management System (LMS) Moodle. The English Moodle-based teaching is a massive pedagogy shift due to pandemic. The study aimed to investigate and explore the technicality feature of teaching English, particularly the studentcentred approach. The study was conducted in the qualitative approach experimental sequential research design. The substantive research instruments applied in the study comprised centred on questionnaires and interviews. The questionnaire was generated to investigate the lecturer used Moodle in their English language teaching. It is expected to discover the utilizing feature and adapting virtual class in LMS Moodle. The findings revealed that the system had an exclusive feature to accommodate studentcentred teaching, yet it was found that the lecturer's unfamiliarity implied the inadequacy of Moodle course feature.
\end{abstract}

Keywords: English for specific purposes; LMS moodle; student-centred approach; teaching English;

\section{A. INTRODUCTION}

Student-centred teaching continues a discussed concept because various studies between educators synchronize and seldom eliminate one another. Frambach et al. (2014) explained that problem-based learning (PBL) is the student-centred educational model selected as this case study's object. The knowledge construction goals are lecturer could conceive circumstances that support students to establish connections of new ideas and develop additional information within their 
fundamental skills and viewpoints among previously acknowledged. Muhamadjonovna (2020) stated the use of new information technologies and Internet resources that help implement a student-centered approach to learning and provide individualization and differentiation of teaching, taking into account students' abilities. Genuine learning is to investigate the learning activities, which are relatable and applicable to the students. Costa (2014: 160) Student-centered education is about teachers investing in developing the learners' potential rather than selecting the whole chunks of content to pass on to students. It highlights the collaborative process, which occurs through interaction with other students. Students can practice contributing feedback and supporting processes.

The student-centred approach embraces the concept that students have a preference for their material and method. Teachers and course materials can be mistaken; teachers are co-learners and students; knowledge is changeable and subject to debate (Jacobs, 2014). The approach concentrated on the student's necessities, capabilities, enthusiasms, and learning styles with the lecturer as a facilitator of learning. The lecturer implemented the primary concept of material to be accessed simply by the students. Buditama (2017) expressed that the studentcentered direction is proper for independent and self-managed learners; it participates in what, how, and when to learn and creates their own learning experiences. In terms of activities, Information and Communication Technology supports students to accomplish elaborate tasks using multi-modal information. Those adjustments do not take point as different aspects; they are intermingled. Learning with technology implies a participatory and self-regulatory procedure, while student-centered learning benefits from e-learning and Web 2.0 tools (Muianga, 2018).

The starting position for all language teaching should be an understanding of whereby people learn. It is only reasonable that the lecturer's expectation intends to create a vast development in communicative English foreign language. Lecturers 
need to observe the detailed information related to the student's ability to learn English. Calvo (2007: 192) explained that learner-centered teaching seems especially suited to teaching a second language, activity, or process that has to do more with learning how to do things than knowing things. English Specific Purposes (ESP) course is improved derived from an assessment of objectives and demands. ESP concentrates more on language in the circumstances than approaching teaching grammar and language structures. Fallahrafie (2015) stated that ESP courses receive a great deal of attention and emphasis among the English Foreign Learning (EFL) practitioners and learners, especially at universities. Most ESP learners in Indonesia are well informed of the significance of communicative ability in studying a foreign language. They needed to accomplished the complexity of four abilities in the workplace environment. In a similar argument, Basturkmen (2004) cited as Skrill (2018, p110.) stated language is acquired not for its own sake or to obtain a general education, but to facilitate entry or increase linguistic efficiency in academic, professional, or workplace settings. Arghli (2016,p.401) English for Specific Purposes is a term that refers to teaching or studying English for a specific career, such as law, medicine, or business in general, i.e., there is a reason for English to be learned.

The vast advantage of technology had been theoretically shown to provide teaching ESP. Dashtestani (2016) argued that the condition encouraged ESP practitioners to integrate computer-assisted language learning (CALL) features in their ESP modules. The integration involved various internet-based learning management systems to classroom learning and teaching in inspiring the study of the digital generation nowadays. Jeong (2017) added that technology-integrated learning, such as e-learning, m-learning, or computer-assisted language learning (CALL), has had a meaningful influence on learning and teaching. The industrial revolution era has an impact on the students' daily life. They live encircled and facilitated by computers, the Internet, smartphones, and other forms of technology. 
Harjanto and Sumarni (2019) asserted that their (students) dependence on technology evolves their learning behaviours, making them quickly get dull when a lecturer only explains without visual images or provides them with the printed material.

According to Dashtestani and Stojkovic (2016: 435), the application and integration of technology in English for Specific Purposes (ESP) contexts may present challenges and opportunities that are distinct from those encountered in English as a Foreign Language (EFL) contexts. The particular advantages of utilizing technology in ESP education involve implementing interactive and communicative activities associated with students' professions, programs, or explicit purposes. The application of technology collaborated student-centred has been struggling implemented in higher education in Indonesia. In the new normal of the pandemic, the learning model in higher education in all zones for theoretical material is achieved online (Directorate General of Higher Education of Indonesia, 2020). The usage of online learning required development in the infrastructure and advanced system. Santoso (2019) asserted that the Internet is an essential requirement to use massive open online courses (MOOC). Internet provision in regions outside Java Island needs to be improved to be aligned with MOOC implementation.

The previous research conducted a comparison, application, and utilization to the Moodle in English teaching and learning (Lin, 2013; Hobbs, 2013; Zhang, 2016; Gundu, 2017). Nonetheless, there have been inconsiderable confirmation of importance might be incorporated in the particular contexts of EFS and LMS Moodle. Shalatska (2020) affirmed that the Moodle course lets the teacher, instructor, or lecturer conserve considerable time to concentrate on communicative assignments. The findings of the study had several practical implications in EFS online courses improvement. Accordingly, the study was principally designated to investigate the specific LMS Moodle feature that accommodates English for 
specific purposes in student-centred teaching and explore the English lecturer's versatility in LMS Moodle online learning environment

According to the previous description, the study's significance appears to focus on applicable moodle to facilitate student-centered English for specific purposes, particularly the system's activities feature. The result impacted to enhance and explore the adaptability in the online learning ecosystem. The investigations attempted to answer these following questions

1. What challenges do lecturers always have in teaching based Moodle?

2. What did the Moodle feature have to accommodate Student-Cantered Approach?

\section{B. RESEARCH METHOD}

The study was conducted in the qualitative approach exploratory sequential research design. Qualitative survey research implies a limited structured research methodology to obtain in-depth information about the lecturer's elemental experience, perspective, and rationalization. The end purpose is to develop an extensive understanding of the student-centered approach collaborated by utilizing LMS Moodle in teaching English from an individual perspective. A collective case study concerns investigating more than individual cases to examine a phenomenon, population, or customary condition in the process of delivering English for specific purposes in the LMS Moodle ecosystem.

Twenty-three full-time English lecturers participated in the Jakarta area. The alphabetic code A, B, and C are related to the institution's background, and the second numerical number referred to the interview sequence. The similarity condition implied to the experience for them to utilize LMS Moodle as the alternative virtual class. They expressed closely similar problems to adapt to the new technology, such as the online system's inexperience and limited time to prepare the content. Eighteen lecturers were familiar with the teaching collaborated 
with technology, and five lecturers were conventional approachable in the regular class meeting.

The substantive research instruments applied in the study comprised centred on questionnaires and interviews. The questionnaire was generated to investigate the lecturer used Moodle in their English language teaching. It is expected to discover the utilizing feature, adapting virtual class in LMS Moodle, expanding their online teaching abilities. Two parts of the questionnaires converged on the lecturer's background knowledge in English language teaching at higher education and endeavored to examine Moodle's use.

There were 18 questionnaires online google form distributed to respondents. The questionnaire applied to determine what the respondents do or have done in the past related to Moodle usage. Eight lecturers were interviewed for the convenience and preferences of LMS Moodle features. Interviews were conducted with the mobile phone for their accessibility. The collected data was analyzed, applying a standard procedure to manage, transcribe, coding, reduce, interpret, and formulate the conclusions. The collected data was analyzed, applying a standard procedure to manage, transcribe, coding, reduce, interpret, and formulate the conclusions. The data analysis was accomplished to interpret the reduced data by connecting to the Moodle activities, and resource feature collaborated in student-centered teaching EFS. The interpretation was coordinated and triangulated to formulate answers to the research questions

\section{FINDINGS AND DISCUSSION}

According to the interview results, lecturers were classified into two groups based on Moodle's experiences: 12 lecturers collaborated with Moodle before the pandemic, and 11 others did not collaborate with Moodle at all. The 3.17 moodle version is implemented in their e-Learning. Three higher institutions had different characteristics to utilize the Moodle. Universitas Budi Luhur had an official 
regulation conducting the course. Meanwhile, two others (Universitas Mercubuana and Universitas Pamulang) had flexibility utilizing the course in Moodle

\section{What challenges do you always have in teaching based Moodle?}

Student-centered teaching proved accommodated to teaching a foreign language center on real activity and lied on the process. The approach managed to observe language learning as acquiring abilities. English pedagogy and technology collaboration established a student-centered approach applicable in the other tools, particularly the learning management system. On the other hand, the Studentcentred instructional adapted and adjusted to the virtual class's accessibility in Moodle. According to the respondent's complete survey and depth-interview, there are several crucial features in LMS Moodle utilized in student-centred English teaching.

1. We knew about the instructional design of student-centered. The approach is designed to give and support student communicative needs. However, Moodle was lack of synchronous activity, mainly to the inaccessibility of the conference meeting. (C.01)

2. Student-centered implied the interactive teaching approach. We are using another application to overcome the communication problem. The application was accommodated enough to teach English, yet it is designed to have asynchronous e-Learning. (A.08)

The Moodle learning environment can provide technological learning tools and is referred to as individual personal tools and collaborative personal tools if it is well designed. However, the shifting of face-to-face class to virtual class made many English lecturers reluctant. The Student-centered Moodle English teaching utilizes technological tools commensurate with specific learning activities based on social constructivist and social constructionist learning principles 


\section{Adapting traditional class to online class}

Lecturers had various encounters with online classes. The restriction regulation amid pandemic in Higher Education shifts the traditional class to the online class. The adjustment took time for all aspects of learning and teaching. The Lecturers' and instructors' terms implied the different functions in the e-Learning context. They need to understand comprehensible all the aspects theoretically and practically in the Moodle system.

3. Teaching online environment is more challenging than in a face-to-face class. You (lecturer) need to provide the solution to each technical problem face by the student. The lecturer might become not only a lecturer but also managerial and technical competencies. (B.02)

4. The lecturer is only delivered material and reconfirms the information to students. The situation cannot be similar in the traditional class because the student would have needed online support for a length of time (C.02)

5. If I had the option to choose, I would instead teach in a traditional class rather than online. The online class spent much time arranging a reliable and adapted class. We need to maintain every detail of information in the course, and it was made sure to be followed by the student. For me, it was my difficulty because I was not good at technology (C.05)

The virtual classroom enhances a student-centered learning situation, in contrast to the traditional classroom teacher-centered setting. The traditional classroom is composed of moderately broadcast communication, a platform for the instructor's information delivery. This transformation of importance was in impassable decline to the instructor's attention. The electronic classroom develops the instructor's position. In establishing a Moodle learning environment, the lecturer must carefully determine the intellectual and social structure within the class's communication for understanding. The teaching capacity is not shifting discarded, 
but the role is signifying transformed enormously. Faculty necessity recognizes the position of instructional technology, virtually a learning resource, and denoting capability at both content and process. The instructor engaged and dedicated facilitation function unconventional of the traditional classroom potential. The lecturers should be exceedingly concentrated on the adaptation of dissimilar learning environments. However, unusual problems accommodate these new learning situations. These adapting concerns to the environment are associated with conceding the concept and the work method.

\section{Communication Problem}

It is essential to maintain the lines of communication clear among lecturers and their students. Frequent contact encourages the participants to develop a recalibration and reconfirmation of the Moodle course. It helps maintain student engagement with the content and activities involved in the Moodle class. Many students and lecturers comprehend the transition from an in-person, traditional classroom to online communication being a significant loss. The discrepancies in whence social interactions happen online or in-person are of prominent matter.

6. Moodle chat feature is one of the things that does not work in my class. I was not so sure. The system failed to accommodate the online chatting room. We expected to have fast and reliable communication, but it would not have in the chat feature. we adjusted to the outside chat application in our smartphone to facilitate our communication (A.10)

7. It was an unpleasant experience having a discussion or conversation in the online facility. We know it took time for us to adjust to the situation. Unfortunately, I felt disturbed if my student sends me a message at night when I was a rest. (C.04)

8. Moodle had given us (lecturer) the exclusive feature. I can give a suggestion, advice, or feedback in the assignment or quiz feature. It was 
my point of view that the way we represent those activities something missing. we cannot make a personal approach as emotional feeling to those (students) made a similar mistake or had bellow average of the class (A.03)

The necessary technical equipment must be provided. Sufficient hardware, software, and an Internet connection implied of high importance to anticipate technical barriers. Moreover, the necessity of technical expertise between the lecturers and the students has to be approached. Communication barriers can appear through the complete online education process. It includes a course outline, improved course elements, implementation of online collaborative working conditions, etcetera. The following barriers directly or indirectly induce communication: technological, mechanical, educational, emotional, and individual barriers

\section{What did the Moodle feature have to accommodate Student-Cantered Approach?}

The full online learning has been adapted with the COVID-19 regulation striction direct meeting in the institution's class. The lecturer has been teaching for more than three years on average. It has been arranged into two groups, five lecturers were actively using e-learning for more than two years, and the seven's rest lecturers had just used it for less than two years. The challenge has been shown in the depth-interview, including the unfamiliarity with the system and limited time to prepare.

9. The institution regulations had a specific layout for the students during online class in the pandemic. The goals are to take the attention and flexibility of every participant following the Moodle course. I am personally using it for the quiz, assignment, file, chat, attendance, etcetera. (A.06)

10. It has a very different approach to complete material in Moodle or online learning. I took the time to utilize it (Moodle) and created a convenience 
course in Moodle. Our department must create with the minimum features such assignment chat choice external tool forum glossary, book, file, folder, and label (B.02.)

11. It is a new thing for me. I am professionally considering time to prepare for the virtual class. Moodle is our institutionally learning management system. However, I am not familiar with the system, such as quizzes, labels, assignments, attendance, and chat. (A.08.)

According to the general respondents' interviewer and close questioners, the majority did not collaborate with the class's pedagogy with technology before the pandemic occurred. It took time for them to adjust to the e-learning ecosystem. They were manually learned from another source to create an attractive layout for their students. The forum group discussion has maintained the lecturer to support many questions related to the system. Work from home also made a huge impact for them to complete the course in Moodle. Their professionalism was tested to manage the time, despite the activity as the father or mother. They need more time than work in the office so prepare the complete course might be challenging for every lecturer

Table 1 Utilization of LMS Moodle Feature Teaching

\begin{tabular}{cc}
\hline \multicolumn{2}{c}{ Feature Moodle } \\
\hline Activities & Resources \\
\hline Assignment & Book \\
\hline Chat & File \\
\hline Choice & Folder \\
\hline External tool & Label \\
\hline Forum & \\
\hline Glossary & \\
\hline Lesson & \\
\hline Quiz & \\
\hline Survey &
\end{tabular}


What student-centered approach did you implement to teaching ESP Based Moodle?

\section{Inquiry-Based Learning}

Inquiry-based learning comprises a pedagogy approach to emphasizes the student's position in the learning process. Preferably than perceiving them related to the information, students are inspired to explore the material, suggest questions, and experience ideas. Thus, they are not just listening or rewriting what they are learning. Alternatively, they get the opportunity to examine a topic more intensely and discover from their own unique experiences each individual.

The Moodle features signify adjustable from the regular meeting to the virtual meeting. In the sense of the inquiry-based learning approach, instructors or lecturers were advised to adopt Moodle activities feature of the forum, glossary, lesson, quiz, and survey. These features of activities indeed accommodated the creativity of the instructor or lecturer, progressing the Inquiry-based learning. Upload the best topic from another internet-based media to the forum, lesson, and quiz; ask the students to respond to each issue.

12. I need to be more creative to engage and motivate our students to accomplish the activity. Label created detailed information about the topics and file features and managed all the extension files, including word, pdf, and ppt. The instruction is sufficient enough for them to choose what they intended to discuss first. Evaluation as a test is crucial for me. It affirmed to the student following the e-learning course systematically. (A.08.)

13. I let the student choose the systematically material each day. I did many tests in the moodle. It was purposely to create productivity in my ESP class. I was confused for the first time, but I was comfortable enough to apply in the forum, assignment, and quiz. (B.01.) 
Students construct their associations concerning what they must prepare as future secretarial and administrative personnel, such as work-related communication with English associates in the office, describing the job position to other employees (policy, cultural regulation, etcetera). This matter allows them to learn a topic adequately than they would prepare by remembering and memorizing details. Inquiry-based learning has specific criteria to be followed by every lecturer. The purposes are to determine the teaching method in their virtual class.

Table 2 Inquiry-Based Learning Moodle Based Feature

\begin{tabular}{|c|c|}
\hline $\begin{array}{c}\text { The Inquiry-Based Learning } \\
\text { Instructional }\end{array}$ & The LMS Moodle Feature \\
\hline Confirmation Inquiry & $\begin{array}{l}\text { 1. Assignment } \\
\text { 2. Quiz } \\
\text { 3. Forum }\end{array}$ \\
\hline Structured Inquiry & $\begin{array}{l}\text { 1. Assignment } \\
\text { 2. Forum }\end{array}$ \\
\hline
\end{tabular}

\section{a. Confirmation Inquiry}

The question and the method (answer clue) are given to the students. The goal is to confirm the idea and practice their investigative skill in English as a foreign language. Moodle is supportive of accomplishing this instruction. The lecturer can utilize the feature of assignment, quiz, forum. The assignment activity module facilitates a lecturer to communicate assignments, collect work, and provide grades and feedback.

\section{b. $\quad$ Structured Inquiry}

The lecturer presents the primary question and a profile of the scheme. Learners continue to express explanations of their conclusions through evaluating and analyzing their interpretation of the material. The Moodle ecosystem can complete with a particular feature. The feature accommodated the activities of the question in Assignment or Forum. These two features elaborate on the skill measure of the 
student's ability in English. The student submitted an assignment feature, any digital content (files), such as word-processed documents, spreadsheets, photographs, or audio and video clips. On the other hand, The forum activity module allows participants to have asynchronous discussions over an extended period.

\section{Problem-based learning}

Problem-based learning is a pedagogical approach to concentrate on students' problems during the process of gaining knowledge. The function is to have students independently in finding solutions based on existing problems. The topic could be modified from future secretarial or administrative personnel. The lecturer or instructor can have a group discussion with the student to have students' perspective about the ideal business correspondence in email, dealing with complaints, arranging some reservation place, and others.

14. In the traditional face-to-face class, I usually start the meeting with some daily topics to be discussed with my students. LMS Moodle took a different approach to me. I apply with the feature of forum and assignment. This feature made writing abilities improve. (C.03.)

15. I enjoyed teaching in online learning, and it was exploring my pedagogy technicality. Moodle feature had many advantages to accommodate teaching ESP. The beginning class started with some news topics for my students. Those topics include newspaper articles, videos, and many others. I implemented labels, files, or URL features in Moodle. (A.05.)

The lecturer or instructor communicates a knowledge foundation consisting of fundamental ideas, guidance, sources, relationships, and abilities needed to complete the material's purposes. Moodle's resources can cover this material feature using the label, books, or file. The lecturer or instructor could be designed a scenario problem for their material, and then the student responded to the problem from their perspective. Each student had the same portion to express the idea. The speaking 
activity test can be done by utilizing the assignment feature. the student might get a recorded video and upload it to Moodle so the lecturer or instructor can have detailed information to make some evaluation for scoring

Table 3 Problem Based Learning Moodle Based Feature

\begin{tabular}{ll}
\hline $\begin{array}{c}\text { The Problem Based Learning } \\
\text { Instructional }\end{array}$ & The LMS Moodle Feature \\
\hline Problem Assigned & 1. Files \\
& $\begin{array}{l}\text { 2. Label } \\
\text { 3. URL }\end{array}$ \\
\hline Identify what student need to & $\begin{array}{l}\text { 1. Wiki } \\
\text { know }\end{array}$ \\
& 2. Glossaries \\
& 3. Lesson \\
Learn and Apply to solve the & 1. Quiz \\
problem & 2. Assignment \\
& 3. Forum \\
\hline
\end{tabular}

\section{a. Problem Assigned}

Problem Based Learning can support the improvement of critical thinking abilities, problem-solving abilities, and communication abilities. The lecturer performs as a facilitator, and the learning is intended to solve the problem. The problem is not always with the question but also the statement, and it should be related to the material in English teaching for specific purposes. The moodle is implemented the feature with Files, Label, and URL. A file might utilize to share presentations and insert a mini website as course support. This function provides design files of software applications so learners can compose and submit them for assessment. On the other hand, the label feature facilitates text and multimedia to be embedded into the course layout page, and The URL feature empowers a lecturer to implement a web link virtually a course resource. Anything that is openly available online.

b. Identify anything students require to know 
Problem-based learning is designed to improve and develop critical thinking ability in English material. The student should be more active find and select the possible answer in language learning. Feature of Wiki, Glossaries, and Lesson are adapted to this phase. The wiki activity lets participants attach and select a compilation from web pages. A wiki can be collaborative among everyone remaining versatile. Lecturers can be attached to glossary entries inside of the glossary feature. The appointed concepts are presented in the insertion. The keyword can be examined or surveyed alphabetically or category. The lesson feature allowed lecturers to deliver material and practice activities in exciting and manageable ways. A teacher can apply the lesson to build a linear set of content pages or instructional activities that offer various paths or possibilities.

\section{c. Acquire and Implement to solve the problem}

The last step implies identifying significant resources for learners. They necessitate learning, identify, and utilize learning resources independently. It can help the lecturer designate several reliable sources to get them started. Quiz, Assignment, and Forum features are designated to support the phase of PBL. As mentioned before, these features were empowered and supported the lecturer design to guide learners to overcome their problem in communication as the goals of English for specific purposes

\section{Brainstorming, Discussion, and Case Study}

Brainstorming supports critical thinking abilities. The students were required to understand the concept of knowledge; they could elaborate on their perspectives. Meanwhile, Discussion is implemented in various forums for the open-ended, collaborative dialogue of ideas among the participants to further students analyzing, receiving, problem-solving, comprehension, or literary recognition. The case studies method may be casually explained practically using real-life circumstances in companies for pedagogical purposes, studied 
independently, and discussed in groups with a lecturer's help. Participants display various points of view, counter to others' ideas, and think on their ideas to develop their conversance, understanding, or interpretation of the English for specific purposes.

16. We clearly cannot interact directly (face to face) in Moodle. If we want to have some discussion, I apply the feature of forum and chat. The disadvantage of Moodle is the lack of an interactive synchronous system. The feature of assignment and quiz is sufficient enough to accommodate the teaching ESP context. (C.03)

17. We cannot replace the efficient and emotional aspect of online learning. We can answer the question with all of the resources, but we are missing something. It is interactive in natural ways. Since we were teaching English, the main language is to communicate spontaneously. However, I was applied with chat, forum, quiz, or assignment if my class wanted some particular discussion (B.07)

Table 4 Learning Instructional Moodle Based Feature

\begin{tabular}{cc}
\hline Learning Instructional & The LMS Moodle Feature \\
\hline Brainstorming & 1. Chat \\
& 2. Forum \\
\hline Discussion & 3. Quiz \\
Case Study & 4. Assignment \\
\hline
\end{tabular}

Forum, assignment, quiz, and external tools covered the activities. Lecturer and student can subscribe to a forum to accept notifications of the latest forum posts. A Lecturer can initiate the subscription mode to unrestricted, compelled, or auto, or restrict subscription completely. If required, students have the opportunity to post more than a given number of posts in a given period; this can engage individuals from communicative discussions. 
Lecturer and student can subscribe to a forum to accept notifications of the latest forum posts. A Lecturer can initiate the subscription mode to unrestricted, compelled, or auto, or restrict subscription completely. If required, students have the opportunity to post more than a given number of posts in a given period; this can engage individuals from communicative discussions. Brainstorming implies the problem-solving method. It engages one to multiple participants in the process of thinking innovation and producing creative ideas. The brainstorming technique typically prepares for quality enhancement and is regularly the developing point towards forming a strategic indicator.

\section{CONCLUSION AND SUGGESTION}

\section{Conclusion}

The findings established that English as foreign language abilities frequently signified significant professional workers and staff personnel. English communication made a tremendous advantage for their career but also opened a broader opportunity in society. Their job was crucial to maintain direct and indirect communication in the workplace, and English is the connected language from another non-Indonesian employee. An English Specific Purposes (ESP) course is developed based on assessing purposes, needs, and activities. ESP centers more on language in context in the real situation than on teaching grammar and language structures. The English program's comprehensive choice is when the main idea about creating complex abilities usage by communication verbally and orally. ESP concentrates more on language in context than on teaching grammar and language structures

\section{Suggestion}

The result found the enormous topic that significant to discovered. The LMS Moodle is the popular electronic learning ecosystem in Indonesia. It should be completed to explore the capabilities to adjust with electronic testing (e-testing) and 
compare other learning management systems such as google classroom. The English for specific purposes had a specialized to the communicative competence. Thus the adaptability to the Learning management system became so much important. it is to measure the capabilities of LMS Moodle to learn and teach English

\section{E. REFERENCES}

Baghli, A. (2016). Learning English for Specific Purposes. Journal of Teaching English for Specific and Academic Purposes, 4(2), 399-416.

Buditama, M. (2017). Student-centered learning approach in teaching basic grammar. Journal on English as a Foreign Language, 7(2), 209-226.

Calvo, A. S. (2007). A learner-centred approach to the teaching of English as an L2. ES: Revista de filología inglesa, (28), 189-196.

Costa, M. J. (2014). Self-organized learning environments and the future of studentcentered education. and Health Sciences Research Institute (ICVS), DOI 10.1002/bmb.20781

Dashtestani, R., \& Stojkovic, N. (2016). The use of technology in English for Specific Purposes (ESP) instruction: A literature review. Journal of Teaching English for Specific and Academic Purposes, 3(3), 435-456.

Directorate General of Higher Education. (2020). Panduan Penyelenggaraan Pembelajaran Semester Gasal 2020/2021 di Perguruan Tinggi. Ministry of Education: Indonesia

Fallahrafie, Z., Rahmany, R., \& Sadeghi, B. (2015). The effect of task-based teaching on incidental vocabulary learning in English for Specific Purposes. Fen Bilimleri Dergisi (CFD), 36(3).

Frambach, J. M., Driessen, E. W., Beh, P., \& Van der Vleuten, C. P. (2014). Quiet or questioning? Students' discussion behaviors in student-centered education across cultures. Studies in Higher Education, 39(6), 1001-1021 
Gundu, N., \& Ozcan, D. (2017). Implementation of the Moodle system into EFL classes. Profile Issues in Teachers Professional Development, 19, 51-64.

Harjanto, A. S., \& Sumarni, S. (2019, May). Teachers'experiences On The Use Of Google Classroom. In English Language and Literature International Conference (ELLiC) Proceedings (Vol. 3, pp. 172-178).

Hobbs, M., \& Hynson, Y. (2013). Development and use of Moodle for online student support. Studies in Self-Access Learning Journal, 4(3), 196- 207.

Jacobs, G. M., \& Toh-Heng, H. L. (2013). Small steps towards student-centered learning. In P. Mandal (Ed.), Proceedings of the international conference on managing the Asian century (pp. 55-64). Singapore: Springer

Jeong, K. O. (2017). The use of Moodle to enrich flipped learning for English as foreign language education. Journal of Theoretical \& Applied Information Technology, 95(18).

Lin, C. H. (2013). Using Moodle in a general education English as a second language program: Taiwanese college student experiences and perspectives. Journal of Educational and Social Research, 3(3), 97-97.

Muhamadjonovna, S. D. (2020). The development of sociolinguistic competence of future English language teachers through computer technologies. European Journal of Research and Reflection in Educational Sciences, 8 (3) Part II, 147, 150.

Muianga, X., Klomsri, T., Tedre, M., \& Mutimucuio, I. (2018). From TeacherOriented to Student-Centred Learning: Developing an ICT-Supported Learning Approach at the Eduardo Mondlane University, Mozambique. Turkish Online Journal of Educational Technology-TOJET, 17(2), 46-54.

Santoso, H. B. (2018). Indonesian Perspective on Massive Open Online Courses: Opportunities and Challenges. Journal of Educators Online, 15(1). 
English Education: Jurnal Tadris Bahasa Inggris pISSN 2086-6003 | eISSN 2580-1449

Vol. 14 (1), 2021, 115-135

Skril, I. (2018). Peculiarities of Lesson Planning and its Running in Teaching English for Specific Purposes for Prospective specialists in hospitality and restaurant service. DOI 10:25128/2415-3605.18.2.15

Zhang, X. (2016). Student-centered College English Teaching based on Moodle Platform. In 2016 5th International Conference on Social Science, Education and Humanities Research. Atlantis Press. 